\title{
Pandemics, cities and Public Health
}

\author{
Nelson Gouveia \\ Claudio Kanai
}

${ }^{I}$ Department of Preventive Medicine, Faculty of Medicine, University of São Paulo São Paulo/SP - Brasil

${ }^{I I}$ Department of Preventive Medicine, Faculty of Medicine, University of São Paulo São Paulo/SP - Brasil

\begin{abstract}
Public Health and urban planning, which were once strongly connected, now go separately and are practically united only in sanitation policies. New and old health threats brought by urbanization and highlighted by the current pandemic emphasized the close relationship between health and the urban environment. Measures to control the current SARS-Cov-2 pandemic resulted in cleaner urban environments, particularly with lower levels of air pollution in many cities due to drastic reduction in economic activity and mobility patterns. COVID-19 is also related to air pollution by possibly increasing susceptibility to infection and the lethality of the disease. Both aspects are discussed in view of the recent literature and empirical data for the city of Sao Paulo. In preparing for the post-pandemic, health should be back at the center of decisions regarding urban life and urban planning and Public Health re-connected.
\end{abstract}

Keywords: Public health; city planning; air pollution; communicable diseases

São Paulo. Vol. 23, 2020

Debating ideas

The COVID-19 epoch: Interdisciplinary research towards a new just and sustainable ethics

DOI: http://dx.doi.org/10.1590/1809-4422asoc20200120vu2020L3ID 


\section{Introduction}

Pandemics and epidemic outbreaks have always been part of the history of cities. Higher population density, greater likelihood of contacts between people and inadequate basic infrastructure, such as absence of potable drinking water and sewage collection, are some of the conditions associated with the presence and spread of infectious diseases in the urban environment. Likewise, since very early in history, Public Health has dealt with these diseases through policies and actions that belong to the field of urban planning. Take the example of the classic cholera epidemic in London in the 19th century when the British physician John Snow identified that cholera was transmitted by contaminated water, an observation that later resulted in the recognition of sewage systems for cities as an essential urban service (NEWSOM, 2006). Snow and other prominent figures of that time were possibly the precursors of a line of thought that considered the interaction between public health and urban planning as crucial for promoting health and quality of life for the population (BRIMBLECOMBE, 2019).

In fact, the best-known legacy of that period was the adoption of sanitation systems as a public policy, although even today these services are not fully universalized in many cities on the planet (WHO, 2019). However, as urbanization increases and cities become larger and denser, new threats and old health problems emerged, enhanced by or as a direct consequence of the deterioration of the environment (GOUVEIA, 1999).

The current SARS-CoV-2 pandemic the world is experiencing has again highlighted the close relationship between health and the urban environment. On the one hand, because it uncovers how human action changing or destroying biodiversity creates the conditions for the emergence of new viruses (DASZAK; CUNNINGHAM; HYATT, 2001). On the other hand, by revealing how housing conditions, population density, and the precariousness of sanitary and transport infrastructure, features that usually follow rapid urban expansion and population growth, are challenging the capacity of governments in keeping the epidemic expansion under control. Added to this is the fact that the production of urban space and its relationship with health and disease is mediated by the issue of social inequalities that modulates societies' response to epidemics.

Beyond the problems related to housing and sanitation, less usual aspects of the interaction between health and the urban environment have gained prominence in this current pandemic. For example, lockdown, quarantine and other measures of physical distancing adopted by numerous countries as the only effective way to control the accelerated spread of the virus have led to a drastic change in the patterns of energy production and consumption. As a result, we observed cleaner urban environments, and particularly a noticeable drop in levels of ambient air pollution in many cities around the world.

The health hazards associated with breathing dirty air are well known and documented and the World Health Organization (WHO) recommends countries to adopt air quality standards to protect the health of the population (WHO, 2006). The current Covid-19 pandemic interrelates with urban air pollution in two complementary ways: through its impact on urban levels of air pollution and by the association of air pollution with mortality from Covid-19. 


\section{Impact of the pandemic on air pollution levels}

The first noticeable aspect of the relationship between air pollution and the pandemic was the significant reduction in ambient levels of pollutants which was initially depicted from satellite images from Wuhan, China (NASA, 2020). Cities have been struggling to reduce their current ambient levels of pollution but it was the sudden reduction of economic activity and population mobility, resulting from measures to contain the epidemic, that helped achieving this difficult goal.

The city of Sao Paulo has experienced similar situation of reduction in the level of economic activity in response to the advent of the coronavirus and it was noticeable a reduction in the volume of vehicles circulating in the streets. To examine what has happened in terms of air pollution we collected data on daily mean levels of fine particulate matter (PM2.5 - particles of $2.5 \mu \mathrm{m}$ or smaller), the air pollutant most associated with health effects (WHO, 2018). Data were obtained from the Environmental Company of the State of São Paulo (CETESB) through the QUALAR system (CETESB, 2020). Data were collected only for monitoring stations located in the Metropolitan Region of São Paulo (MRSP). For each station, the average concentration for the month of April for the years between 2017 and 2019 and, separately, for 2020, was calculated in order to assess the difference in concentration during a period affected by the pandemic and of previous years. Applying criteria adopted by CETESB (2019), monitoring stations that did not have daily or monthly representative data in the period covered in this analysis were excluded in order to reduce the noise introduced by incomplete measurements, match the number of monitors examined and maintain data comparability.

In addition, the daily average for the months of March and April 2020 was also examined, comparing with data of a social isolation index (SÃO PAULO, 2020) collected from the Intelligence Monitoring System of São Paulo (SIMI-SP) to assess the behavior of isolation during the months of March and April 2020. This index uses data generated daily from the mobile phone network to monitor the displacement of the population in the territory and indicates the portion of the population that is fulfilling the isolation measure.

Except for one air quality monitoring station, for which the average concentrations remained stable, a reduction in PM2.5 levels were observed in the other 9 included in this analysis (Table 1). On average, there was a $10.4 \%$ reduction in ambient concentration levels of PM2.5 in April 2020, under quarantine, compared to the average of the last 3 years. 
Table 1 - Average concentrations of PM2.5 for April 2017. 2019 and 2020 and the difference observed betw een the two periods by monitoring station. São Paulo, 2017-2019 and 2020

\begin{tabular}{c|c|c|c|c} 
Monitoring station & $\begin{array}{c}\text { Scale of spatial rep- } \\
\text { resentativeness }\end{array}$ & $\begin{array}{c}2017-2019 \\
\left(\mu \mathrm{g} / \mathrm{m}^{3}\right)\end{array}$ & $\begin{array}{c}2020 \\
\left(\mu \mathrm{g} / \mathrm{m}^{3}\right)\end{array}$ & \% difference \\
$\begin{array}{c}\text { Cid.Universitária-USP- } \\
\text { Ipen }\end{array}$ & Urban & 13.5 & 12.8 & -5.1 \\
\hline Congonhas & Micro & 17.3 & 14.4 & -16.5 \\
\hline Grajaú-Parelheiros & Micro & 14.9 & 12.7 & -14.8 \\
\hline $\begin{array}{c}\text { Guarulhos-Paço } \\
\text { Municipal }\end{array}$ & Urban & 15.9 & 14.6 & -7.7 \\
\hline Ibirapuera & Urban & 13.1 & 9.8 & -25.6 \\
\hline Itaim Paulista & Urban & 14.2 & 14.3 & 0.7 \\
\hline $\begin{array}{c}\text { Marg.Tietê-Pte Remé- } \\
\text { dios }\end{array}$ & Micro & 16.3 & 15.9 & -2.9 \\
\hline Parque D.Pedro II & Neighborhood & 15.0 & 13.7 & -9.2 \\
\hline Pico do Jaraguá & Urban & 13.9 & 11.2 & -19.3 \\
\hline S.Bernardo-Centro & Neighborhood & 14.9 & 14.1 & -5.7 \\
\hline Mean MRSP & & 14.9 & 13.4 & -10.4 \\
\hline
\end{tabular}

Note $\left(^{*}\right)$ : Microscale (up to $100 \mathrm{~m}$ ), medium scale (between $101 \mathrm{~m}$ and $500 \mathrm{~m}$ ), neighborhood scale (between 501 and $4000 \mathrm{~m}$ ) and urban scale (4000 $\mathrm{m}$ to $50,000 \mathrm{~m})$. Source: the authors.

The greatest reductions were observed in 2 stations that, according to CETESB (2019), have an "urban" scale of spatial representativeness, that is, the measurements are representative for an environment whose radius varies from $4 \mathrm{~km}$ to $50 \mathrm{~km}$. Examining the exact location of the stations, we noted that these two are located very far from traffic routes and, therefore, are the ones that can best represent the background concentrations of air pollution.

Comparing the daily levels of pollution with the isolation index we observed that there was a slightly decrease in the concentration of PM2.5 as the index increases (Figure 1 ), with a low correlation (Pearson $r=-0.26$; $p$-value $=0.074$ ). At the end of April 2020 there was an increase in levels of PM2.5 while the isolation index was stable. It should be stressed that the temporal pattern of air pollution levels is influenced by several other factors not considered in the present assessment, such as meteorological conditions. Nevertheless, these results are compatible with another assessment carried out for São Paulo that examined the impact of quarantine on air quality (FREITAS et al., 2020). 
Figure 1 - Daily mean levels of PM2.5 and the isolation index in the Metropolitan Region of Sao Paulo, 2020

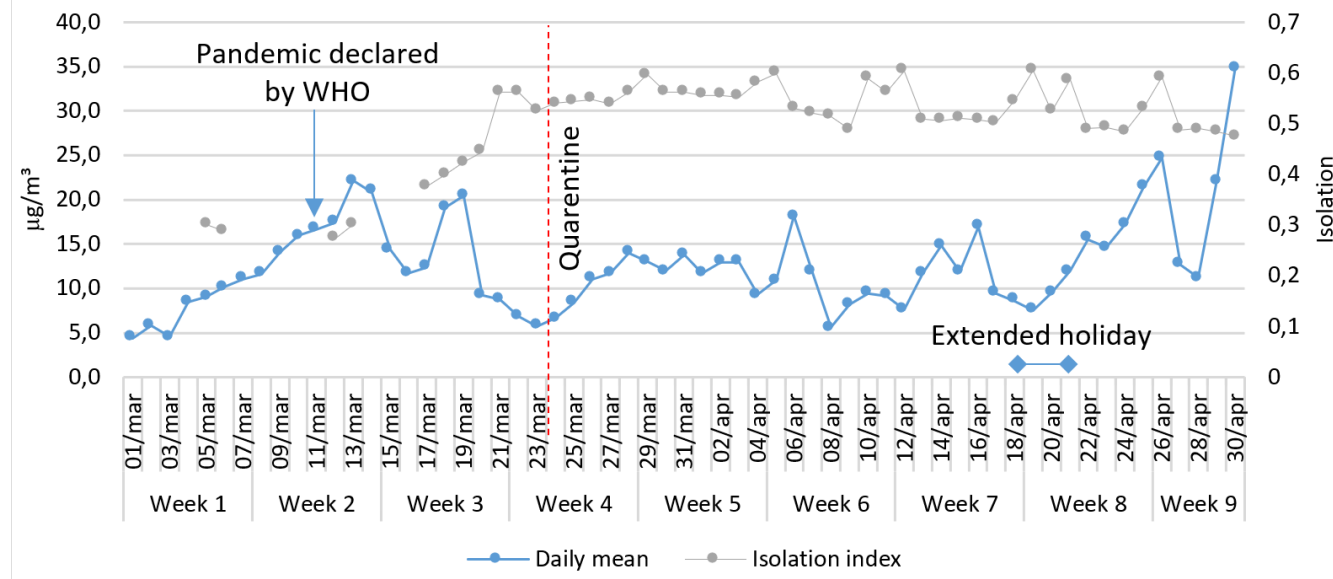

Source: the authors

Covid-19 contention measures have resulted in cleaner air in São Paulo as it had in many other cities around the world. Average reductions of around 39\% and 32\% in PM2.5 concentrations were found in the regions of Delhi and Shanghai, respectively, comparing the years 2019 and 2020 (LI et al., 2020; MAHATO; PAL; GHOSH, 2020). In Beijing, a reduction of almost $6 \%$ was observed comparing the pre- and post-quarantine weeks in 2020 (BAO; ZHANG, 2020). These reductions in ambient air pollution certainly translate into health gains for the population. However, one should bear in mind that these measures and their impact are temporary and thus, do not address the problem of urban air pollution in the medium and long term. To achieve a sustained and effective reduction in levels of air pollution a city needs coordinated investments in transport systems with emphasis on clean mass transport, and encourage active mobility such as walking and cycling, among other possibilities. The lesson to be learned from the current moment is that it is possible to control air pollution in urban areas by reducing the circulating fleet. This certainly involves costs, but we are witnessing how a health emergency becomes a priority over the economy. It should also be clear to policy makers that the benefits of decreasing air pollution levels outweigh by far the costs (CIFUENTES et al., 2001).

\section{Air pollution, incidence and lethality of Covid-19}

The second aspect of the relationship between ambient pollution and the pandemic is the connection to mortality from Covid-19 that has recently attracted a lot of attention. Studies are suggesting that air pollution should be considered an additional cofactor to explain the lethality of SarsCov-2. A report by scientists in Italy noted that the high mortality rates observed in the north of the country correlated with the higher 
levels of air pollution (CONTICINI; FREDIANI; CARO, 2020). In the U.S., a study compared levels of fine particulate matter (PM2.5) in 3,080 cities between 2000 and 2016 and the mortality rates for COVID-19 in the same locations during the first weeks of the pandemic. They concluded the death rates were 15\% higher in the areas most exposed to these harmful particles in recent years (WU et al., 2020). Although, to date, there is no proven link between air pollution and mortality from COVID-19, similar association was observed with previous strains of coronavirus during the SARS epidemic outbreak in 2002 in China (CUI et al., 2003).

However, the strength of the evidence brought by these studies, mostly of an ecological design, is still small. In addition, little is known about the virus responsible for this pandemic and the pathophysiological mechanisms triggered by it. It is also unknown the true incidence or the mortality rate of COVID-19 in the population, since in each country deaths are computed differently and the detection of cases depends on the ability to perform tests.

On the other hand, we know that long-term exposure to high levels of air pollution impairs lung function and increases the vulnerability to respiratory diseases, especially infections (WHO, 2006). Air pollution has also an acute effect on the lungs as evidenced by short-term increases in mortality and hospital admissions due to respiratory diseases associated with increases in daily levels of air pollution (WHO, 2006).

In addition, air pollution is an important risk factor and contributes to the establishment of the main chronic diseases that increase the severity and risk of death from Covid-19, such as hypertension, diabetes and cancer (ZHENG et al., 2020). Chronic exposure to air pollution weakens individuals and increases their susceptibility to these chronic conditions and those with co-morbidities are at a higher risk of death under this pandemic.

Air pollution has also an acute effect impairing the immunological defense of the lungs making individuals more prone to infections (WHO, 2006). Therefore, it can aggravate the disease in those who get Covid-19, although this has never been studied since the virus is new (WU et al., 2020).

Another possibility that has been discussed is that airborne particulate matter would help spread the virus as it can bind on the aerosol surface. However, this is the hypothesis with less consensus and more uncertainty. Results of studies on the airborne transmission of SARS-CoV-2 are contradictory (HADEI et al., 2020; VAN DOREMALEN et al., 2020).

Whether or not there is a causal relationship between poor air quality and the incidence or lethality of the new coronavirus, this pandemic might have made many realize the importance of clean air in the cities. Places with high levels of pollution should perhaps take extra measures to slow down the spread of the virus and use extra resources to deal with the outbreak, in the light of the precautionary principle. Thus, it is imperative to continue looking for actions to combat high levels of air pollution in cities considering their potential impacts on the health of the population. 


\section{Conclusion}

Public health and urban planning were strongly connected, especially when infectious diseases were the main health concern. However, over time this relationship has been lost and partly restricted to sanitation issues. In the meantime, urbanization has escalated and cities have grown sometimes making mistakes that only became apparent after decades, such as channeling rivers, waterproofing the soil, and emphasizing individual motorized transport. Patterns of urbanization are linked to population health through various pathways such as loss of natural habitat for species, changes in disease vectors, or increased levels of ambient air pollution.

Urban environment degradation must decrease even if under strong pressure for further growth. Recently there have been calls for urban planning and public health to re-connect (GILES-CORTI; WHITZMAN, 2012; KOOHSARI; BADLAND; GILESCORTI, 2013). Increasingly, urban spaces are recognized as important social determinants of health with the potential for negative and positive effects on physical and mental health (KLEINERT; HORTON, 2016).

As the coronavirus pandemic impacts millions across the world and put economies in a standstill, many are rethinking their way of living and their modes of consumption. Perhaps, this is also a time to claim the cities back to people, to explore the role and opportunity of urban planning to improve health and well-being.

For the case of urban air pollution, there are countless measures that can be taken in order to improve air quality. For example, cities can adopt stricter legislation for the emission of pollutants, develop mechanisms to encourage the adoption of cleaner processes by industry, devise compact neighborhoods, enforce more sustainable transportation systems, and promote active transport such as cycling and walking.

Policies in the most varied areas can affect human health but this has rarely been taken into consideration in the decision-making process. In preparation for the postpandemic, it is time to bring health at the center of decisions regarding urban life. This should be seen as an opportunity to move forward to a more sustainable and healthier future with less air pollution.

\section{References}

BAO, R.; ZHANG, A. Does lockdown reduce air pollution? Evidence from 44 cities in northern China. Science of The Total Environment, [S. 1.], v. 731, n. 1954, p. 139052, 2020. Disponível em: https://doi.org/10.1016/j.scitotenv.2020.139052

BRIMBLECOMBE, P. City and environment. City and Environment Interactions, [S. 1.], v. 1, p. 100005, 2019. Disponível em: https://doi.org/10.1016/j.cacint.2019.100005

CETESB - COMPANHIA AMBIENTAL DO ESTADO DE SÃO PAULO. Qualidade do ar no estado de São Paulo 2018. São Paulo: [s. n.], 2019. Disponível em: https://cetesb.sp.gov.br/ar/ wp-content/uploads/sites/28/2019/07/Relatório-de-Qualidade-do-Ar-2018.pdf 
CETESB - COMPANHIA AMBIENTAL DO ESTADO DE SÃO PAULO. Qualar. [s. 1.], 2020. Disponível em: https:/qualar.cetesb.sp.gov.br/qualar/home.do. Acesso em: 2 maio. 2020.

CIFUENTES, L. et al. Assessing the Health Benefits of Urban Air Pollution Reductions Associated with Climate Change Mitigation (2000-2020): Santiago, Sao Paulo, Mexico City, and New York City. Environmental Health Perspectives, [S. 1.], v. 109, n. SUPPL. 3, p. 419, 2001. Disponível em: https://doi.org/10.2307/3434790

CONTICINI, E.; FREDIANI, B.; CARO, D. Can atmospheric pollution be considered a co-factor in extremely high level of SARS-CoV-2 lethality in Northern Italy? Environmental Pollution, [S. 1.], v. 261, p. 114465, 2020. Disponível em: https://doi.org/10.1016/j.envpol.2020.114465

CUI, Y. et al. Air pollution and case fatality of SARS in the People's Republic of China: an ecologic study. Environmental Health, [S. 1.], v. 2, n. 1, p. 15, 2003. Disponível em: https://doi. org/10.1186/1476-069X-2-15

DASZAK, P.; CUNNINGHAM, A. A.; HYATT, A. D. Anthropogenic environmental change and the emergence of infectious diseases in wildlife. Acta Tropica, [S. 1.], v. 78, n. 2, p. 103-116, 2001. Disponível em: https://doi.org/10.1016/S0001-706X(00)00179-0

FREITAS, E. D. et al. Mobility Restrictions and Air Quality under COVID-19 Pandemic in São Paulo, Brazil. [S. 1.], n. April, p. 1-14, 2020. Disponível em: https://doi.org/10.20944/preprints202004.0515.v1

GILES-CORTI, B.; WHITZMAN, C. Active living research: Partnerships that count. Health and Place, [S. 1.], v. 18, n. 1, p. 118-120, 2012. Disponível em: https://doi.org/10.1016/j.healthplace.2011.09.010

GOUVEIA, N. Saúde e meio ambiente nas cidades: os desafios da saúde ambiental. Saúde e Sociedade, [S. 1.], v. 8, n. 1, p. 49-61, 1999. Disponível em: https://doi.org/10.1590/S010412901999000100005

HADEI, M. et al. A Letter about the Airborne Transmission of SARS-CoV-2 Based on the Current Evidence. Aerosol and Air Quality Research, [S. 1.], v. 20, n. 5, p. 911-914, 2020. Disponível em: https://doi.org/10.4209/aaqr.2020.04.0158

KLEINERT, S.; HORTON, R. Urban design: an important future force for health and wellbeing. The Lancet, [S. 1.], v. 388, n. 10062, p. 2848-2850, 2016. Disponível em: https://doi.org/10.1016/ S0140-6736(16)31578-1

KOOHSARI, M. J.; BADLAND, H.; GILES-CORTI, B. (Re)Designing the built environment to support physical activity: Bringing public health back into urban design and planning. Cities, [S. 1.], v. 35, p. 294-298, 2013. Disponível em: https://doi.org/10.1016/j.cities.2013.07.001

LI, L. et al. Air quality changes during the COVID-19 lockdown over the Yangtze River Delta Region: An insight into the impact of human activity pattern changes on air pollution variation. Science of The Total Environment, [S. 1.], v. 732, p. 139282, 2020. Disponível em: https://doi. org/10.1016/j.scitotenv.2020.139282

MAHATO, S.; PAL, S.; GHOSH, K. G. Effect of lockdown amid COVID-19 pandemic on air quality of the megacity Delhi, India. Science of The Total Environment, [S. 1.], v. 730, p. 139086, 
2020. Disponível em: https://doi.org/10.1016/j.scitotenv.2020.139086

NASA - NATIONAL AERONAUTICS AND SPACE ADMINISTRATION. Airborne nitrogen dioxide plummets over China. [s. 1.], 2020. Disponível em: https://www.earthobservatory. nasa.gov/images/146362/airborne-nitrogen-dioxide-plummets-over-china. Acesso em: 18 maio. 2020.

NEWSOM, S. W. B. Pioneers in infection control: John Snow, Henry Whitehead, the Broad Street pump, and the beginnings of geographical epidemiology. Journal of Hospital Infection, [S. 1.], v. 64, n. 3, p. 210-216, 2006. Disponível em: https://doi.org/10.1016/j.jhin.2006.05.020

SÃO PAULO (ESTADO). Adesão ao isolamento social de SP. [s. 1.], 2020. Disponível em: https://www.saopaulo.sp.gov.br/coronavirus/isolamento/. Acesso em: 10 maio. 2020.

VAN DOREMALEN, N. et al. Aerosol and Surface Stability of SARS-CoV-2 as Compared with SARS-CoV-1. New England Journal of Medicine, [S. 1.], v. 382, n. 16, p. 1564-1567, 2020. Disponível em: https://doi.org/10.1056/NEJMc2004973

WHO - WORLD HEALTH ORGANIZATION. Air quality guidelines. Global update 2005. Particulate Matter, Ozone, Nitrogen Dioxide and Sulfur Dioxide. [S. 1.: s. n.]. E-book.

WHO - WORLD HEALTH ORGANIZATION. Ambient (outdoor) air pollution. [s. 1.], 2018. Disponível em: https://www.who.int/news-room/fact-sheets/detail/ambient-(outdoor)-air-quality-and-health. Acesso em: 18 maio. 2020.

WHO - WORLD HEALTH ORGANIZATION. Air quality guidelines: global update 2005: particulate matter, ozone, nitrogen dioxide, and sulfur dioxide. World Health Organization, 2006.

WU, X. et al. Exposure to air pollution and COVID-19 mortality in the United States: A nationwide cross-sectional study. MedRxiv, [S. 1.], p. 1-36, 2020. Disponível em: https://doi. org/10.1101/2020.04.05.20054502

ZHENG, Z. et al. Risk factors of critical \&amp; mortal COVID-19 cases: A systematic literature review and meta-analysis. Journal of Infection, [S. 1.], n. 568, 2020. Disponível em: https://doi. org/10.1016/j.jinf.2020.04.021 


\section{Nelson Gouveia}

$\square$ ngouveia@usp.br

ORCiD: https://orcid.org/0000-0003-0625-0265
Submitted on: 11/06/2020

Accepted on: 13/06/2020

2020;23:e0120

\section{Claudio Kanai}

$\square$ claudiokanai@gmail.com

ORCiD: https://orcid.org/0000-0002-7967-0108

How to cite: GOUVEIA, N.; KANAI, C. Pandemics, cities and Public Health. Ambiente $\mathbb{\&}$ Sociedade. São Paulo, v. 23, p. 1-10, 2020. 


\title{
Pandemias, cidades e Saúde Pública
}

\author{
Nelson Gouveia \\ Claudio Kanai
}

São Paulo. Vol. 23, 2020

Ideias em debate

A época $\mathrm{CO}$. VID-19: Pesquisa interdisciplinar e uma nova ética sustentável e justa
Resumo: A Saúde Pública e o planejamento urbano, que já foram fortemente conectados, agora caminham separadamente e praticamente se unem apenas nas políticas de saneamento. Novas e antigas ameaças à saúde trazidas pela urbanização e destacadas pela atual pandemia enfatizam a estreita relação entre saúde e ambiente urbano. Medidas para controlar a atual pandemia de SARS-Cov-2 resultaram em ambientes urbanos mais limpos, particularmente com níveis mais baixos de poluição do ar em muitas cidades devido à drástica redução na atividade econômica e nos padrões de mobilidade. A COVID-19 também está relacionada à poluição do ar, possivelmente aumentando a suscetibilidade à infecção e a letalidade da doença. Ambos aspectos são discutidos em vista da literatura recente e de dados empíricos da cidade de São Paulo. Ao se preparar para a pós-pandemia, a saúde deve voltar ao centro das decisões relacionadas à vida urbana e o planejamento urbano e a Saúde Pública reconectados.

Palavras-chave: Saúde pública; planejamento urbano; poluição do ar; doenças transmissíveis

Como citar: GOUVEIA, N.; KANAI, C. Pandemias, cidades e Saúde Pública. Ambiente \& Sociedade. São Paulo, v. 23, p. 1-10, 2020. 


\title{
Pandemias, ciudades y Salud Pública
}

\author{
Nelson Gouveia \\ Claudio Kanai
}

São Paulo. Vol. 23, 2020

Ideas en debate

La época CO. VID-19: investigación interdisciplinaria y una nueva ética sostenible y justa
Resumen: La salud pública y la planificación urbana, que ya han sido fuertemente conectadas, ahora van por separado y prácticamente se unen solo en las políticas de saneamiento. Nuevas y viejas amenazas a la salud traídas por la urbanización y destacadas por la pandemia enfatizan la estrecha relación entre salud y medio ambiente urbano. Medidas para controlar la actual pandemia del SARS-Cov-2 resultaron en entornos urbanos más limpios, particularmente con niveles más bajos de contaminación del aire debido a la reducción drástica de la actividad económica y los patrones de movilidad. La COVID-19 también está relacionado con la contaminación del aire al posiblemente aumentar la susceptibilidad a la infección y la letalidad de la enfermedad. Ambos aspectos se discuten en vista de la literatura reciente y datos empíricos de la ciudad de Sao Paulo. Al prepararse para la pos pandémica, la salud debe volver al centro de las decisiones sobre vida urbana y la planificación urbana y Salud Pública reconectadas.

Palabras clave: Salud pública; planificación urbana; contaminación del aire; enfermedades transmisibles

Como citar: GOUVEIA, N.; KANAI, C. Pandemias, ciudades y Salud Pública. Ambiente \& Sociedade. São Paulo, v. 23, p. 1-10, 2020.

DOI: http://dx.doi.org/10.1590/1809-4422asoc20200120vu2020L3ID 